\title{
ПРОПАГАНДА ЯК СОЦІАЛЬНО-ПОЛІТИЧНЕ ЯВИЩЕ: ПРОБЛЕМИ РОЗУМІННЯ
}

\author{
Шевців М. Б., Гончарук К. А.
}

У статmі проаналізовано пропаганду в історичному екскурсі, зокрема встановлено, що пропаганда як соціально-політичне явище мала місце у різних історичних періодах, вона і надалі продовжує впливати на свідомість спільноти, незважаючи на використання проти неї різних методів боротьби. Запропоновано власне визначення пропаганди як форми комунікації, спрямованої на маніпулювання свідомістю конкретно визначеного суб'єкта з метою формування у нього певних уявлень і позицій. Також виокремлено та проаналізовано види пропаганди. За одним поділом - на позитивну та негативну, за іншим - на білу, сіру та чорну пропаганди.

Ключові слова: пропаганда, види пропаганди, позитивна пропаганда, негативна пропаганда, біла пропаганда, чорна пропаганда, сіра пропаганда.

В статье проанализирована пропаганда в историческом экскурсе, в частности установлено, что пропаганда как социально-политическое явление имело место в различных исторических периодах, она и дальше продолжает влиять на сознание общества, несмотря на использование против нее различных методов борьбы. Предложено собственное определение пропаганды - как формы коммуникации, направленной на манипулирование сознанием конкретно определенного субъекта с целью формирования у него определенных представлений и взглядов. Также выделены и проанализированы виды пропаганды. По одному разделению - на положительную и отрицательную, по другим - на белую, серую и черную пропаганды.

Ключевые слова: пропаганда, виды пропаганды, положительная пропаганда, негативная пропаганда, белая пропаганда, черная пропаганда, серая пропаганда.

The article deals with the propaganda in the historical excursus, in particular, it is established that this phenomenon should be associated with the appearance of private property. Propaganda as a social and political phenomenon took place in different historical periods; it continues to influence the consciousness of the community, despite the use of different methods of struggle against it.

The definition of propaganda as a form of communication, aimed at manipulating the consciousness of a specifically defined subject in order to form the certain conception and views is proposed.

An attempt to analyze the types of this social phenomenon is made. In particular, one of the main is the division of propaganda into positive and negative. Positive propaganda promotes the social upbringing based on generally accepted behaviors and social norms. Negative propaganda aims at achieving the goals set by all permitted and prohibited methods. In addition, white, grey and black propaganda are distinguished. White propaganda generally comes from an open source and is characterized by milder methods of persuasion, such as standard public relations techniques and one-sided representation of arguments. Black propaganda is given from one source, but it is actually from the other. The masking of the true source of propaganda is the most broadened when it is the propaganda of a hostile country or organization with a negative image. Grey propaganda - without a definite source or author, is intended to force the enemy to believe in a lie using false arguments.

Key words: propaganda, types of propaganda, positive propaganda, negative propaganda, white propaganda, black propaganda, grey propaganda.

Постановка проблеми та їі актуальність. Завдяки сучасному інформаційному простору сьогодні доступна інформація як у малому, так і у великому масштабах. Правдива і неправдива, безпечна і шкідлива, вона у будь-якому вигляді впливає на свідомість людини. Поширення неправдивої інформації може здійснюватися різними шляхами та способами. Особливої уваги заслуговує характеристика одного із найбільш поширених способів висвітлення неправдивої інформації «пропаганди».

Аналіз досліджень і публікацій. Дослідженню феномена пропаганди, iï складових, видів, методів поширення приділяли увагу багато вчених - як минулого, так і сучасності. Серед класиків правової науки треба згадати Х. Бауса, Г. Лассуелла, С. Московіча, В. Росса В. Шрамма. Із сучасних теоретиків права варто назвати Е. Аронсона, Дж. Брауна, Л. Войтасіка, Г. Джоветона, К. Джонсон-Керті, Т. Квалтерона, Г. Коплендона, В. О’ Донелла, Е. Пратканіс.

Актуальність дослідження. У час перенасичення українського інформаційного простору, багато хто стверджує, що усі події, які сталися в Україні з початку 2014 року, є наслідком нахабного маніпулювання інформацією. Аналіз природи інформаційної пропаганди як складного багатовимірного феномену $\epsilon$ одним із актуальних завдань сучасних міждисциплінарних досліджень, які дають змогу значно розширити межі усталених уявлень про означене явище, застосувати альтернативні методологічні підходи до його наукового дослідження.

Мета статті. Проаналізувати зміст феномену «пропаганда», розкрити та охарактеризувати їі основні види.

Предметом статті $\epsilon$ теоретико-правове дослідження поняття та видів пропаганди.

Об'єктом статті $\epsilon$ інформаційна пропаганда у сучасному суспільстві.

Виклад основного матеріалу. Неможливо точно визначити, коли саме зародилась пропаганда. Проте більшість істориків стверджують, що виникнення цього явища слід пов'язувати із появою приватної власності, що спровокувало поділ суспільства на класи, тобто на багатих та бідних. Таким чином, в будьякій державі правлячий клас (царі, князі, фараони, королі) прагнув за допомогою різних методів примуси досягти власних цілей використовуючи сили нижчого класу.

Шевців М. Б., Гончарук К. А., 2019 
Одним із найбільш ранніх зразків пропаганди можна вважати преамбулу до Зведення законів Хаммурапі, в якій сказано, що ці закони створені для встановлення справедливості в країні і для захисту слабких від сильних. Зміст же самих законів переважно спрямовано саме на захист інтересів заможних верств за рахунок незаможного населення [2].

Проаналізувавши ряд історичних подій, можна помітити, що більшість персон, котрі розв'язувати та вели війни світового масштабу, такі як

А. Македонський, Ю. Цезар, Петро І, Наполеон, Гітлер, Сталін та інші, активно використовували у своїй діяльності пропагандистські механізми.

Але найбільш потужнішим виявився Третій рейх, який дав майстер-клас усім майбутнім диктаторам з управління масами за допомогою пропаганди. Як наслідок, нацистська преса, підконтрольна партії влади, розв'язала найстрашнішу бійню людства. Результатом роботи найпотужнішого дезінформатора XX століття, взірцем інформаційної політики для тоталітарних і авторитарних режимів XXI століття, стало те, що освічені берлінці, століттями не підозрювали про небезпеку стороннього сусідства. У березні 1933-го року, після приходу до влади Nationalsozialistische Deutsche Arbeiterpartei (НСДАП), партії Адольфа Гітлера, нацисти насамперед організували міністерство пропаганди і народної освіти. Його очолив вже на той час відомий в боях з гуманізмом та поширенням пропаганди Йозеф Геббельс [10].

Не здавала свої позиції порівняно з нацисткою пропагандою і радянська, яка була визнана найбільш масштабною у всьому світі. Радянська пропаганда має тривалу історію, яка $\epsilon$ досить важливою, оскільки саме ця пропаганда лежала в основі формування свідомості населення СРСР.

У Радянському Союзі пропаганда мала таке саме велике значення, як військові організації або спецслужби. Вона була зайнята створенням своєї моделі світу, користуючись інструментами не тільки журналістики, а й літератури та мистецтва, кіно і телебачення. Всі вони покликані швидко змінювати наш світогляд та спотворювати реальність подій. Радянська пропаганда також включала в себе проведення масових демонстрацій, які безпосередньо або опосередковано мали свідчити про всенародну підтримку влади. Наприклад два основних свята 7 листопада (День Великої Жовтневої Соціалістичної Революції) і 1 травня (День Перемоги) відрізнялися лише наявністю чи відсутністю військового параду. Свята моделювалися так, щоб відобразити в складі демонстрантів всі професії і всі республіки. Щоправда, такі масові дійства вихваляння влади не були новими формами пропаганди,а відомі ще з часів античності [11].

Як бачимо, пропаганда мала місце в усі історичні часи та активно використовувалось для досягнення поставлених цілей. ІІї способи і методи змінювались відповідно до часу. Варто зазначити, що масове використання пропаганди найчастіше спостерігається в періоди війни чи військових конфліктів, коли перед багатьма державами світу поставала проблема нестачі економічних, політичних, фінансових ресурсів для досягнення перемоги.

Поняття пропаганди має доволі багате історичне минуле. Пропаганда проявлялась у розбіжних варіаціях на різних етапах розвитку суспільства не лише в Україні, а й за ї̈ межами. Саме поняття пропаганди $\epsilon$ досить багатогранним, але в останні роки воно найчастіше застосовується поряд з поняттям інформація. Спробуємо охарактеризувати зміст цього терміна.

у соціологічному енциклопедичному словнику поняття пропаганда розглядається у трьох варіантах: 1) система діяльності, спрямована на поширення знань, художніх цінностей та іншої інформації з метою формування певних позицій, уявлень, емоційних станів, здійснення впливу на соціальну поведінку людей; 2) поширення в масах ідеології та політики певних класів, партій, держав; 3) засіб маніпуляції масовою свідомістю» [3, с. 348].

У політологічному енциклопедичному словнику пропаганда визначається як систематичне здійснення зусилля вплинути на свідомість індивідів, груп, утворень для досягнення певного, заздалегідь визначеного результату в сфері політичної дії [4, с. 683].

Під пропагандою розуміється форма комунікації, яка спрямована на поширення фактів, аргументів, чуток та інших відомостей для впливу на суспільну думку на користь певної спільної справи чи громадської позиції. Велика радянська енциклопедія визначає пропаганду як поширення політичних, філософських, наукових, художніх та інших позицій і ідей з метою їх впровадження в суспільну свідомість і активізації масової практичної діяльності [9].

Пропаганда - це ідеологічно спрямована діяльність партії, громадського об'єднання чи іншої організації для формування у конкретних верств населення певних позицій і уявлень (світогляду). Пропаганда зазвичай поширюється через різні засоби масової інформації, щоб досягнути бажаного результату. На відміну від об'єктивної подачі інформації, пропаганда подає інформацію насамперед для впливу на аудиторію [7].

Пропаганда часто подає інформацію вибірково, щоб спонукати до певних узагальнень, або використовує емоційно заряджені повідомлення, щоб спровокувати радше емоційну, ніж раціональну реакцію на наведену інформацію. Бажаним результатом $\epsilon$ зміна ставлення до суб'єкта в цільовій аудиторії, щоб просувати таємні політичні плани. Пропаганда може використовуватись як форма політичного протистояння [8, с. 65].

Пропаганда являє собою більш-менш систематичні зусилля маніпулювати переконаннями, відносинами чи діями інших людей за допомогою символів (слів, жестів, плакатів, монументів, музики, одягу,тощо). Умисність і відносно сильний акцент на маніпуляції відрізняють пропаганду від звичайного спілкування чи вільного і легкого обміну ідеями. У пропагандиста $\epsilon$ конкретна мета, щоб досягти їі, пропагандист навмисно відбирає факти, аргументи і символи та подає їх так, аби досягти найбільшого ефекту. Щоб максимізувати ефект, він може оминати істотні факти чи спотворювати їх, а також може відвертати увагу аудиторії від інших джерел інформації [12, с. 181].

Американський теоретик комунікації, автор лінійної моделі комунікації, політолог, який велику частину праць присвятив вивченню явища пропаганди Г. Ласвелл, у книзі «Техніка пропаганди у світовій війні», що вийшла в 1927 р., визначає пропаганду як менеджмент колективних уявлень за допомогою маніпуляцій значимими символами [10, с. 74]. 
Вадим Макішвілі у книзі «Большая книга манипуляций. Изучаем секреты управления сознанием» зазначає, що пропаганда - це комплекс заходів для зміни суспільних і політичних позицій людей. Пропаганда поширює певну думку так, щоб людина добровільно погодилась із нею [6, с. 33].

Отже, термін «пропаганда» справедливо набув яскраво негативного забарвлення через поєднання іï з найбільш маніпулятивними та шовіністичними прикладами. Наприклад, нацистська пропаганда, що виправдовувала Голокост та комуністична пропаганда, яка приховувала Голодомор.

Варто зазначити, що спершу пропаганда мала нейтральне забарвлення і могла пов'язуватися із застосуванням, яке було загалом м'яким і невинним, як, наприклад, публічні рекомендації з охорони здоров'я, заохочення громадян брати участь у виборах, заохочення людей повідомляти в правоохоронні органи про злочини та правопорушення.

Мусимо визнати, що в сучасних українських реаліях пропаганда - це насамперед зброя масового ураження, що впливає на свідомість населення, аніж безневинна інформація для регулювання відносин в суспільстві.

Пропагандистська інформація в різні історичні часи по різному сприймалась населенням. Загалом способи подачі інформації, зокрема пропагандистської, мають широкий спектр. Проте єдиного підходу до поділу пропаганди на види немає. Проаналізувавши ряд думок науковців сучасності, зазначимо, що пропаганда класифікується на позитивну та негативну. Розглянемо їх детальніше.

Позитивна (конструктивна) пропаганда прагне повідомити адресату відомості у зрозумілій формі. Мета позитивної пропаганди - сприяти соціальній гармонії, злагоді, вихованню людей відповідно до загальноприйнятих цілей. Позитивна пропаганда виконує виховну та інформаційну функції в суспільстві. Вона здійснюється в інтересах тих, до кого скерована, а не обмеженого кола зацікавлених осіб [12, c. 92].

Негативна (деструктивна) пропаганда нав'язує людям ті або інші переконання за принципом «мета виправдовує засоби». Мета негативної пропаганди - розпалювання соціальної ворожнечі, нагнітання соціальних конфліктів, загострення суперечностей у суспільстві. Основна функція негативної пропаганди - створення паралельної реальності з «перевернутою», або спотвореною системою цінностей, переконань, позицій. Негативна пропаганда активно використовує критику та навіювання, щоб маніпулювати соціальними масами в інтересах невеликої групи осіб [12, с. 92].

Також пропаганда поділяється відповідно до джерела та природи її повідомлення. На думку О. Бойка, $\epsilon$ три види пропаганди. Перший вид - біла пропаганда, яка загалом походить із відкритого доступного джерела та характеризується м'якшими методами переконання, такими як стандартні техніки відносин із громадськістю та однобічне наведення аргументів. Другий вид - це є чорна пропаганда, що подається ніби з одного джерела, проте насправді $\epsilon$ з іншого. Маскування правдивого джерела пропаганди $\epsilon$ найпоширенішим, коли це пропаганда ворожої країни чи організації з негативним іміджем. Та останній вид пропаганди - сіра, без визначеного джерела чи автора. Основне призначення сірої пропаганди полягає в тому, щоб змусити ворога повірити в брехню використовуючи так звані солом'яні аргументи: перша фаза - змусити когось повірити в «А», запускається сіра пропаганда «Б», яка протилежна до «А». У другій фазі «Б» дискредитується використовуючи опудало. Тоді ворог дійде висновку, що «А» - правда [1, с. 27].

Варто зазначити, що найбільшого поширення в Україні набула сіра пропаганда. Саме їі найчастіше використовують як проросійські організації, створені в східно-південних регіонах України, так і безпосередньо російські ЗмІ. Завдання таких інформаційних центрів зводиться до інформаційної дезорієнтації свідомості населення української держави, особливо тієї частини, що проживає на тимчасова окупованій території.

Висновки. Отже, у науковій статті проаналізовано пропаганду в історичному екскурсі, зокрема встановлено, що це явище треба пов'язувати із появою приватної власності. Пропаганда - як соціально-політичне явище мала місце у різних історичних періодах, вона і надалі продовжує впливати на свідомість спільноти, незважаючи на використання проти неї різних методів боротьби.

Пропаганда, на нашу думку, це форма комунікації, спрямована на маніпулювання свідомістю конкретно визначеного суб'єкта з метою формування у нього певних уявлень і позицій.

Також ми спробували проаналізувати види цього соціально-політичного явища. Одним із основних вважаємо поділ іï на позитивну та негативну. Позитивна пропаганда сприяє соціальному вихованню на основі загальноприйнятих правих поведінки та соціальних норм. Негативна пропаганда має на меті досягнення поставлених цілей усіма дозволеними і забороненими методами. Крім того, розрізняють білу, сіру та чорну пропаганди. Різниця між ними полягає в тому, яким чином та з якого джерела подається пропагандистська інформація.

\section{Література}

1. Бойко О.Д. Пропаганда. Політична енциклопедія / Редкол.: Ю.А. Левенець (голова), Ю.І. Шаповал (заст. голови) та ін. Київ : Парламентське видавництво, 2011. $610 \mathrm{C}$

2. Відмінність між журналістикою та пропагандою. StudFiles. 2016. URL: https://studfiles.net/ preview/2265389/page:7/.

3. Волович В.І Соціологія : короткий енциклопедичний словник / За ред. В.І. Воловича; Соціологічна асоціація України. Київ : Укр. центр духовної культури, 1998. $736 \mathrm{c.}$.

4. Герасіна Л.М Політологічний енциклопедичний словник / уклад.: Л.М. Герасіна, В.Л. Погрібна, І.О. Поліщук та ін.; за ред. М.П. Требіна. Харків : Право, 2015. 816 C.

5. Лассвелл Г. Техника пропаганды в мировой войне / Сокр. перевод с англ. в обработке Н.М. Потапова с предисловием М. Гуса. Москва, 1929. 212 с.

6. Макішвілі В.Ю. Большая книга манипуляций. Изучаем секреты управления сознанием. Москва : Окреме видавництво, 2016. 250 с.

7. Методи пропаганди. Studall.org. 2015. URL: http://studall.org/all-149473.html.

8. Ожеван М.А, Шевченко О.В. Війна інформаційна. Українська дипломатична енциклопедія / Редкол.: 
Л.В. Губерський (голова) та ін. Київ : Знання України. 2004. $760 \mathrm{c}$.

9. Пропаганда. Вікіnедія. 2007. URL: https:// wikipedia.org/wiki/Пропаганда.

10. Пропаганда для початківців. Електронний журнал «Новий час». 2016. URL: https://magazine.nv.ua/ journal/2978-journal-no-3/propahanda-dlja-chajnikov. html.

11. Феномен радянської пропаганди. Psyfactor.org. 2015. URL: http://psyfactor.org/lib/propaganda36.htm.

12. Шведа Ю.Р. Політичні партії. Енциклопедичний словник. Львів : Астролябія, 2005. 488 с.
Шевців М. Б., кандидат юридичних наук, доцент, майор поліції, доцент кафедри теорії та історії держави і права, конституційного та міжнародного права Львівського державного університету внутрішніх справ

Гончарук К. А., рядовий поліції, студент 3 курсу факультету № 3 Інституту з підготовки фахівців для підрозділів Національної поліції Львівського державного університету внутрішніх справ 